PLURAL, Revista do Programa de Pós-Graduação em Sociologia da USP, São Paulo, v.15, 2008, pp.47-63

\title{
Sete personagens lobatianas à procura da nação*
}

\section{Elisângela da Silva Santos**}

Resumo: Neste texto tentamos observar a posição de Monteiro Lobato sobre os rumos que a nação brasileira deveria seguir para ter características modernas e desenvolvidas durante a primeira metade do século XX, momento em que o autor destina sua produção literária ao público infantil, e que consolidou como a série literária intitulada $O$ Sitio do Pica-pau Amarelo. Neste trabalho enfocaremos a participação ativa das seguintes personagens: Dona Benta, Narizinho, Pedrinho, Emília, tia Nastácia, tio Barnabé e o Sabugo de Milho Visconde, na consolidação de propostas ao longo da narrativa. Pretendemos buscar elementos de um pensamento social brasileiro contido nestes textos infantis pois, segundo nossa leitura, há nos livros analisados - O Poço do Visconde (1936), Seróes de Dona Benta (1937), Reinaçôes de Narizinho (1932) e Histórias de Tia Nastácia (1937) - uma ideia ou um projeto de nação, pouco reconhecido como tal no debate daqueles anos e no pensamento social brasileiro. Palavras-chave: literatura e pensamento social; nação; literatura infantil; sociedade.

\section{Seven lobatiana's persons searching the nation}

Abstract: During the first half of the twentieth century, part of Monteiro Lobato's literary production was destined to the juvenile public, especially through the series entitled O Sítio do Pica-pau Amarelo. This text analyzes how Lobato expressed through these works a project of a modern and developed Brazilian nation and the ways he proposed to achieve it. Hence, the active participation of characters such as mrs Benta, Narizinho, Pedrinho, Emilia, aunt

* Recebido em 12 de agosto de 2008. Aprovado para publicação em 26 de maio de 2009

* Elisângela da Silva Santos é doutoranda do programa de pós-graduação em Ciências Sociais da Universidade Estadual Paulista "Júlio Mesquita Filho" - Faculdade de Filosofia e Ciências - Unesp/Marília, professora substituta na mesma Universidade e membro do grupo de pesquisa em Literatura e Cinema da Unesp. Este artigo resulta da pesquisa concluída durante o mestrado, cujo título da dissertação é: Monteiro Lobato e suas seis personagens em busca da nação, que obteve o financiamento da Fundaçáo de Amparo à Pesquisa do Estado de Sáo Paulo (Fapesp), defendida no ano de 2008. 
Nastacia, uncle Barnabe and Sabugo de Milho Visconde are focused in $\mathrm{O}$ Poço do Visconde (1936), Seróes de Dona Benta (1937), Reinações de Narizinho (1932) and Histórias de Tia Nastacia (1937). According to our reading, there is one idea or project of a nation in these books that is not so well recognized as such in the debate of those years and in Brazilian social thinking. So, the narrative analysis seeks the consolidation of Lobato's project and the elements of a certain Brazilian social thinking comprehended in these infantile texts.

Keywords: literature and social thinking; nation; juvenile literature; society.

\section{LITERATURA E DESTINO NACIONAL}

O pensamento e a visão de mundo de Monteiro Lobato ressoam muitas vezes a partir das vozes de suas personagens infantis, por isso não acreditamos que sua literatura infantil esteja separada de seus anseios enquanto escritor e crítico da situação econômica, política e social brasileira. No momento em que Lobato volta sua produção para as crianças, talvez pudéssemos afirmar que ele tivesse uma ideia em germe do "projeto literário" a ser desenvolvido tendo em mente a literatura infantil brasileira, que apesar de sustentada como algo alternativo por algumas análises ${ }^{1}$, era pensada por ele como uma ambiciosa reversão da literatura voltada para as crianças vigente até então no Brasil, considerada pelo autor como "besta e pobre". Em suas palavras:

Guardo as tuas notas sobre Malazarte. Um dia talvez aborde este tema. Ando com várias ideias. Uma: vestir à nacional as velhas fábulas de Esopo e La Fontaine, tudo em prosa e mexendo nas moralidades. Coisa para crianças. Veio-me diante da atenção curiosa com que meus pequenos ouvem as fábulas que Purezinha lhes conta. Guardam-nas de memória e vão recontá-las aos amigos - sem, entretanto, prestarem nenhuma atenção à moralidade, como é natural. A moralidade nos fica no subconsciente para ir se revelando mais tarde, à medida que progredimos em compreensão. Ora, um fabulário nosso, com bichos daqui em vez dos exóticos, se for feito com arte e talento dará coisa preciosa. As fábulas em português que conheço, em geral traduçóes de La Fontaine, são pequenas moitas de amora do mato - espinhentas e impenetrável. Que é que nossas crianças podem ler? Não vejo nada. Fábulas assim seriam um começo da literatura que nos falta. Como tenho um

\footnotetext{
${ }^{1}$ Ênio Passiani (2003, p.244) aposta na ideia de que Lobato só passou a escrever para crianças depois de ter iniciado sua "decadência" no campo literário entre os anos de 1925 e 1926, o que teria "empurrado" o autor de Urupês a "novos nichos" nos quais continuaria exercendo seu trabalho de escritor. Passiani questiona o fato de Lobato náo ter se dedicado a este novo gênero após o lançamento de $A$ menina do narizinho arrebitado, mas conclui que, neste momento, Lobato não tinha necessidade de procurar um novo campo de atuação, já que experimentara nos anos 1910 e início dos 1920 um status inabalável. Discordamos desta posição de Passiani, uma vez que encarar a literatura infantil lobatiana como uma espécie de subterfúgio, ou como campo alternativo, é entendê-la como algo menor, que talvez somente tivesse êxito a partir do momento em Lobato estava desmoralizado no campo literário brasileiro canônico, como demonstraria o necrológico de Lobato construído ironicamente por Mário de Andrade.
} 
certo jeito para impingir gato de lebre, isto é, habilidade por talento, ando com a ideia de iniciar a coisa. É de tal pobreza e tão besta a nossa literatura infantil, que nada acho para a iniciação de meus filhos. (LOBATO, 1950, p.104; grifos nossos.)

Partindo das velhas fábulas - portanto, da relação com o tempo mítico - com os aconselhamentos, liçóes, açóes que ocorreriam no plano encantado, Lobato procurou falar a partir do ponto de vista da criança. A fábula seria o "lugar do primitivo", de modelo de seres criados, cujas personagens são, via de regra, animais que pregam uma lição de moral. Entretanto, a ideia desta nova literatura infantil proposta por Lobato se desprende de um tempo mítico, do passado vivido, pois a ênfase oferecida a tal tempo é deslocada para o futuro: a criança (neste caso, a personagem principal) náo está mais presa a um destino traçado ela está capacitada para projetar e criar utopia.

Assim, a vertente seguida por Lobato foi realmente a invenção de algo novo, de uma literatura infantil que modificava aquela existente até entấo. Propunha a consolidação de uma "sociedade criada" em termos ficcionais, mas que muito se relacionava ao "Brasil real do momento". Seguindo a acepçáo de Erich Auerbach (2007), a obra de arte literária é uma espécie de meio utilizado pelo autor para entender as transformaçôes sociais e como elas se dáo. O escritor é capaz de tornar visíveis tais mudanças por meio da arte, e a maneira como os homens veem a si mesmos está diretamente ligada à "realidade exposta".

É a ação cotidiana das "personagens reais" que demonstram que os fenômenos ocorridos no sítio têm uma "raiz social" - e é a partir deste momento que percebemos a proposta de Lobato. $\mathrm{O}$ escritor partiu das fábulas, da ideia do aconselhamento, mas não se limitou aos contos de fadas, onde as circunstâncias sociais, políticas e econômicas estáo ausentes (cf. AUERBACH, 2007, p.452). Transcendeu essa situação ao criar personagens que têm uma ação no mundo, apesar de se tratar de um contexto simplificado e formado literariamente para crianças. Justificamos a importância da influência da sociedade brasileira sobre os textos de Lobato, a partir das palavras de Auerbach, que afirma: "O puramente literário, mesmo no grau mais elevado da compreensão artística e em meio à maior riqueza das impressóes, limita o juízo, empobrece a vida e à distorce, por vezes, a visão dos fenômenos" (AUERBACH, 2007, p.454).

Ao Brasil das primeiras décadas do século XX colocava-se o desafio de constituir-se como naçáo moderna e o escritor de $O$ Sitio do Pica-pau Amarelo tinha projetos para esse futuro, acreditando que as crianças teriam um importante papel a cumprir para a constituiçáo desse novo modelo de país. Vemos nesta sua literatura a "concretização" de uma proposta de desenvolvimento nacional, perpassada por muitos temas e temáticas caras no âmbito do pensamento social brasileiro, que ora ressoam na ambientaçáo, ora nos projetos realizados na fantasia dos personagens e muitas vezes na própria composição dos mesmos.

Antonio Candido, no texto A literatura de dois gumes (1989, p.163), afirma que a expressão literária, assim como outras expressóes artísticas, se caracteriza por uma 
liberdade que ultrapassa as nossas servidóes, entretanto, por se consolidar como um sistema de produtos que também são instrumentos de comunicação entre os homens, possui diversas ligaçóes com a vida social. A partir da análise do crítico, julgamos válido pensar a correspondência e a interaçáo do "projeto literário-pedagógico" de Lobato com as questôes que enfrentava o país na época. Em debate estavam a industrialização, o progresso, a nossa mão de obra, a vocação agrária brasileira, e o modernismo das letras e das ideias, só para citar algumas das questôes mais em evidência na época. Neste sentido, compreendemos e interpretamos a literatura de Lobato como um fator histórico, político e social e entendemos que na sua forma se materializam aspectos fundamentais da nossa organização social, da mentalidade e da cultura brasileira: "Justamente pelo fato de manter relaçôes com a realidade social, a literatura incorpora as suas contradiçóes à estrutura e ao significado das obras" (CANDIDO, 1989, p.167).

Antonio Candido, em seu livro A formação da literatura brasileira (1959, p.26), nos diz que a partir da Independência do Brasil, os autores passaram a considerar a atividade literária como parte do esforço de construção do país livre, cumprindo um programa estabelecido que visava à diferenciação e particularização dos temas, assim como das formas de exprimi-los. A isso Candido atribui tanto a tomada de consciência dos autores e intelectuais quanto ao protagonismo que desempenharam no processo de organizaçáo racional do país. Portanto, ao transpor as relaçôes sociais para o estilo literário, Lobato interiorizou o país de modo diferenciado, fazendo a crítica à estrutura real, isto é, histórica e brasileira. É com base nos argumentos acima apresentados que propomos incorporá-lo à galeria de nossos pensadores sociais.

\section{EMÍLIA E O VISCONDE: A PARTICIPAÇÃO DAS PERSONAGENS MÁGICAS}

Monteiro Lobato, conforme afirma André Luiz Vieira de Campos (1986 p.26), se recusava a aceitar a ideia de que o Brasil fosse um país novo, pois o pensava sempre como "velho de mentalidade". Tal atraso mental, ocasionado pelo atraso material, fazia com que os jovens estudantes brasileiros jamais pensassem no trabalho como forma de redenção dos males nacionais, e este seria um dos motivos para escrever uma literatura infantil que projetasse uma nova mentalidade para as crianças.

No Sítio do Pica-pau Amarelo, lugar onde Lobato teria projetado um ideal de país que condiz com suas posturas ideológicas, como por exemplo, a mentalidade das suas personagens, que deveria se diferenciar daquela que o autor acusava como sendo carcomida de velha. Em seu sítio, havia uma espécie de intelectual que reunia todas as características benéficas para o desenvolvimento nacional: praticidade, pensamento crítico e racional, adesão à ciência e ao conhecimento de modo geral. Esse intelectual aparece sob a figura de um sabugo de milho, o Visconde de Sabugosa, portanto, uma figura imaginada e colocada como forma de crítica aos nossos intelectuais. Com Visconde, Lobato quis dizer que foi preciso um sabugo científico para a solução do 
problema nacional que mais o incomodava: a falta de exploração dos recursos naturais e a ausência de industrializaçáo.

Visconde, ao contrário dos bacharéis, não advém de uma elite proprietária e não é humano: foi confeccionado por Tia Nastácia e é composto por um sabugo de milho, mas sua qualidade está num cérebro que pensa e age. Na fala de Emília, a boneca falante, vemos a importância deste sabugo de milho para a exploraçáo de petróleo no sítio: "Num país onde até os ministros não pensam em petróleo, ou quando falam nele é para negar, só mesmo dando a palavra a um Sabugo. Viva o Senhor Visconde do Poço Fundo!" (LOBATO, 1968, p.62).

O fenômeno do bacharelismo, muito criticado por Lobato, fora enfocado por Gilberto Freyre em Sobrados e Mucambos (2006, p.601). Para o autor, os últimos tempos coloniais marcaram a consolidação do bacharel e do mulato como "elementos de diferenciaçáo", no interior de uma sociedade rural e patriarcal, onde a diferenciaçáo e os antagonismos sociais eram definidos somente a partir de dois estratos: o senhor e o escravo. A ascensáo do bacharel (ou doutor) trouxera para o Brasil, segundo Freyre, uma "fuga da realidade", uma vez que muitas leis foram copiadas da França, Inglaterra, Portugal, lugares onde os filhos de proprietários, em sua maioria, foram concluir seus estudos:

A valorizaçáo social começara a fazer-se em volta de outros elementos: em torno da Europa, mas uma Europa burguesa, donde nos foram chegando novos estilos de vida, contrários aos rurais e mesmo aos patriarcais: o chá, o governo de gabinete, a cerveja inglesa, a botina Clark, o biscoito de lata. Também roupa de homem menos colorida e mais cinzenta, o maior gosto pelo teatro, que foi substituindo a igreja; pela carruagem de quatro rodas que foi substituindo o cavalo ou o palaquim; pela bengala e pelo chapéu-de-sol que foram substituindo a espada de capitáo ou de sargento-mor dos antigos senhores rurais. (FREYRE, 2006, p.602.)

Sérgio Adorno, em Aprendizes do Poder - o bacharelismo liberal na política brasileira, procurou analisar as relaçóes sociais subjacentes à profissionalização dos intelectuais a partir da análise do juridicismo liberal criado pela vida acadêmica paulista. Em sua análise, esse autor mostra que os bacharéis em direito se destacavam como atores importantes na constituiçáo do Estado Nacional. Uma parte de parlamentares e homens públicos que compunham a elite política do Império compreendia bacharéis em direito que viviam para a política. Mas, por outro lado, esses bacharéis, em sua maioria, manifestavam comportamento influenciado pelo liberalismo econômico e político. Entretanto, diferentemente do liberalismo europeu, os princípios liberais brasileiros adquiriram um caráter antimetropolitano e significavam, no máximo, a luta contra os monopólios e privilégios instituídos e apropriados pela coroa portuguesa antes da Independência do Brasil. A criação e fundaçáo dos cursos jurídicos no Brasil na primeira metade do século XIX foi alimentada com a mesma mentalidade dos principais movimentos sociais, baseada no individualismo político e no liberalismo econômico. 
A consolidação do nosso Estado Nacional defendeu a autonomia cultural, bem como a burocratização do aparelho estatal:

O bacharel acabou por constituir-se, portanto, em sua figura central porque mediadora entre interesses privados e interesses públicos, entre estamento patrimonial e os grupos sociais locais. A criação de uma verdadeira intelligentsia profissional liberal, nascida no bojo da sociedade agrário-escravista, compreendida, na sua grande maioria, de bacharéis, promoveu a ampliação dos quadros políticos e administrativos, sedimentou a solidariedade intraelite de modo a rearticular as alianças entre os grupos sociais representantes do mundo rural e do mundo urbano e, sobretudo, possibilitou a separação entre o poder doméstico e poder público, fundamental para a emergência de uma concepção de cidadania. (ADORNO, 1988, p.78.)

$\mathrm{Na}$ visão de Monteiro Lobato, tal separação entre poder doméstico e poder público, na sociedade brasileira, náo foi a marca da conduta desses intelectuais, pois sempre se aproveitaram das oportunidades de acesso e promoção em carreiras públicas pautadas na indicação de pessoas influentes e conhecidas politicamente. E este aspecto é alvo de constantes críticas lobatianas destinadas aos nossos intelectuais, que não possuíam, conforme ele, o rigor de uma intelligentsia profissional liberal, mas sim o vício da velha prática vigente no Brasil, onde o privado se sobrepunha ao público.

Interpretando o pensamento lobatiano, seria esse tipo de intelectual uma das parcelas sociais brasileiras mais prejudiciais à população em geral. Em seu conto "Um suplício moderno", publicado no livro Urupês, de 1918, ele já acusava o empreguismo público destes "falsos sábios":

O centro move-se, faz cores um papelório através de várias salas onde, comodamente espaçada em poltronas caras, a burocracia gorda palestra sobre espióes alemáes. Depois de demorada viagem, o papelório chega a um gabinete onde impa em secretária d'eimbuia, fumegando o seu charuto, um de réis por mês; é filho d'álgo; entra às onze e sai às três, com folga de permeio para uma "batida" no frege da esquina. (LOBATO, 1994, p.74.)

A fim de vencer esta "burocracia gorda", observa Campos (1986, p.53), era necessária, na concepção de Lobato, a criaçáo de escolas técnicas, que fossem capazes de vencer a mentalidade bacharelesca. Assim como era necessário acabar com a "mania de grandeza" do governo, que construía verdadeiros palácios para abrigar uma oficina gráfica encarregada de imprimir a revista do Supremo Tribunal.

Visconde, portanto, é colocado pela narrativa como o construtor do projeto de exploração do petróleo no sítio de Dona Benta, recurso natural tido pelos seus habitantes como o responsável pelo desenvolvimento da "nação" e que, além disso, colocará fim à inércia comum aos nossos "falsos sábios bacharéis". Essa ineficiência é mostrada de forma mais intensa no livro $\mathrm{O}$ poço do Visconde. Nele, a ciência aparece mais focada no aspec- 
to que envolve a falta de industrialização brasileira, mais especificamente na questão da exploração dos recursos naturais. Para muitos críticos do autor ${ }^{2}$, há aí um tom panfletário - e, ao mesmo tempo, didático - que serviria aos seus leitores como uma espécie de incentivo para uma postura crítica sobre a inércia dos nossos governantes e pensadores em relação ao processo de industrializaçáo.

Entretanto, as personagens, ao terem a ideia de abrir o táo sonhado poço de petróleo, perceberam que, apesar da inteligência e ciência do Visconde, faltava o financiamento:

-Como vai ser? - perguntou Pedrinho voltando-se para Narizinho - como iremos abrir o nosso poço, se estamos completamente limpos de capitais?

-Isso é lá com você, que é homem - respondeu a menina -Dinheiro é assunto masculino: arrume-se.

Pedrinho começou a pensar - e estaria até agora pensando se Emília não resolvesse o problema com a maior facilidade.

-Ora a grande coisa! - disse ela - nada mais simples. Aplica-se o "faz de conta" e logo aparece tudo quanto estamos precisamos - sondas, verrumas de perfurar, tubos de encanamentos, tatus perfuradores - e até petróleo! Você bem sabe que não há o que resista ao faz de conta... (LOBATO, 1968, p.71).

As personagens Visconde de Sabugosa e Emília são caracterizados por Zinda Maria Carvalho de Vasconcellos (1982, p.140) como pertencentes à dimensáo do maravilhoso, como se o autor tivesse deslocado suas esperanças na sociedade real e nos seres humanos para o mundo da fantasia. Para a autora, Emília pode ser caracterizada da seguinte maneira: "Não socializada, a boneca diz bem alto os pensamentos mais censurados por todos, age segundo os impulsos normalmente reprimidos, quebra os padróes aceitos" (ibidem, p.143). Visconde desempenharia: "[...] o papel de transmissor da voz da prudência e experiência adquirida que aqueles [os adultos] desempenham normalmente..." (ibidem, p.140).

Emília, a boneca de pano que não ultrapassa os 40 centímetros de tamanho, aparece para solucionar um "assunto masculino" que Pedrinho não conseguira resolver. A aplicaçáo do faz de conta pela boneca poderia ser entendida como uma espécie de crítica que Monteiro Lobato fazia à nossa burocracia, vista por ele como parasitária, improdutiva, criadora de interesses pessoais, além de sufocadora da livre iniciativa e corrupta. A boneca consegue romper com todos esses impedimentos aplicando um simples faz de conta, e sua esperteza e seu poder de facilitar os aspectos mais impossíveis de realidade acabam por conferir-lhe um lugar de destaque no sítio. Pode-se pensar, no entanto, que ao conferir tanto poder de solução à alguém que não existe na realidade, Emília represente a utopia de seu criador, que através dela "fala" mais alto.

\footnotetext{
2 Como LAJOLO, 1985; ZILBERMAN, 2005; CAMPOS, 1986, entre outros.
} 
Campos observa que Lobato, em sua condição de escritor, se sentia muito incomodado com o fato de viver numa sociedade com uma maioria de analfabetos e com uma classe de proprietários pouco adepta à cultura letrada. No sítio, projetou situaçóes muito diferentes através de suas personagens principais: Dona Benta, apesar de proprietária, é letrada, ensina e incentiva os planos aos netos, explicando a eles desde o conhecimento científico e pragmático até filosofia.

Portanto, neste sítio/Brasil, a maioria é alfabetizada, e tem pensamento crítico e empreendedor. Os sábios agem e trabalham como Visconde que, apesar de velho e costurado, não pensa em se aposentar, como faria qualquer um dos nossos reais jovens "sábios" brasileiros, denominados por Lobato de "parasitas intelectuais" e seguidores do empreguismo público conquistado por meio de favores e das relaçóes pessoais de prestígio.

\section{DONA BENTA E O PODER FEMININO NA ORGANIZAÇÃO SOCIAL E POLÍTICA DO "SÍTIO/BRASIL"}

Num momento em que o poder masculino no lar abrangia aquele previsto pela leidesde a distribuição dos recursos materiais e simbólicos até o uso da violência e o poder de decisão dos diversos aspectos da vida familiar, como, por exemplo, o local e tipo da formação educacional e profissional dos filhos - cabia à Dona Benta desempenhar em sua propriedade todas essas funçôes. $\mathrm{O}$ que pode ser visto como um avanço no modo organizacional de vida do Sítio/Brasil, pois neste ambiente rural - que no Brasil da época era marcado pela forma de organizaçáo masculina e patriarcalista - ocorreria aquilo que não existia nem nos grandes centros urbanos.

Ainda neste sentido, a narrativa de Lobato contrasta duas formas de organização de propriedade: uma organizada por Dona Benta e outra por homens, como o Coronel Teodorico e o caboclo Chico Piramboia. O sítio é caracterizado pelo investimento da proprietária, adepta da forma moderna de produção; já na fazenda do coronel e nos pedaços de terras que o caboclo tem para plantar, são utilizadas técnicas de produzir vistas como arcaicas pela narrativa.

Dona Benta sempre estaria atenta às novidades da ciência, pois assim poderia aproveitá-las para o uso prático em seu sítio, ou para repassá-las às crianças:

Dona Benta costumava receber livros novos, de ciência, de arte, de literatura. Era o tipo da velhinha novidadeira. Bem dizia o compadre Teodorico: "Dona Benta parece velha mas não é, tem o espírito mais moço que o de jovens de vinte anos”. (LOBATO, 1981, p.501.)

Ideias de modernidade e capitalismo estão presentes nos ensinamentos passados por Dona Benta às crianças. Percebemos que, durante todo os livros da série do Sitio do Pica-pau Amarelo, conceitos como ciência, progresso e técnica são transmitidos como sendo parte de um saber considerado universal pelos habitantes do sítio. 
O fato da propriedade de Dona Benta ser um sítio e não uma fazenda demonstra uma perspectiva de modernizaçáo que encontraria paralelo no modelo norte-americano da pequena propriedade tecnificada, altamente produtiva e gerida no nível individual. Com uma propriedade menor, Dona Benta não teria um grande número de colonos a seu encargo, nem em mira a produçáo monocultora. Isto, porém, náo reduz as aspiraçóes econômicas da matriarca e de seus netos, como veremos através de seus ousados investimentos.

O desejo da velha senhora é que o "conhecimento universal" seja desvendado e aplicado na prática. Os exemplos fornecidos por ela às crianças sobre essas aplicaçóes sempre fazem alusáo aos Estados Unidos, o que pode ser observado quando estudam sobre a água. Ela explica que a cidade de Nova York possuiria o maior serviço de águas do mundo. Armazenada em vários reservatórios, permitiria que cada novaiorquino pudesse consumir mais de 400 litros de água por dia. Diferentemente do caso brasileiro onde as cidades seriam abastecidas com águas de riachos, outras vezes com águas dos poços artesianos ou ainda, em lugares mais pobres, através de poços simples ou cacimbas, como ocorreria nas redondezas do sítio.

Em muitas passagens, as comparaçóes entre Brasil e Estados Unidos seguem sempre reforçando a superioridade do segundo. Lobato sempre se demonstrou crítico da falta de exploração dos recursos naturais que o nosso subsolo poderia nos proporcionar. Essa preocupação é transferida às suas personagens, como podemos notar nos seguintes discursos de Dona Benta: [...].

Povo que não tem, ou não explora, carvão ou petróleo é povo sem indústria e pobre

O ferro é o metal mais precioso porque é o mais útil, o mais abundante e a matéria fundamental da civilizaçáo. [...] o ferro é a substância com que o homem constrói suas máquinas e é da máquina que vem o progresso, a riqueza, a civilização[...].

Cada ano os EUA extraem de seu subsolo riquezas no valor de 100 milhóes de contos. Infelizmente cá no Brasil ainda não nos voltamos para o subsolo - apesar de termos na mesma proporçáo que os americanos, já que o território dos dois países mais ou menos se equivalem. (LOBATO, 1966, pp.210-215.)

Desta forma, podemos inferir que no sítio/Brasil projetado pela narrativa lobatiana, a concepção econômica que nortearia a sua administração seria o liberalismo, tal como exprime Dona Benta ao alertar seus netos sobre seus maiores problemas, vistos a partir da sua propriedade. Apesar de sua organização doméstica náo dispensar comodidades da vida patriarcal, Dona Benta no gerenciamento de sua propriedade, raciocina como liberal.

De acordo com os autores do livro Furacão na Botocúndia, Monteiro Lobato teria enveredado pelo caminho do feminismo ao estabelecer no Sítio do Pica-pau Amarelo o matriarcado como modelo ideal de organizaçáo social. Entretanto, esse feminismo que compreende um movimento favorável à equiparação dos direitos civis e políticos da 
mulher aos do homem, se restringe no sítio apenas à classe da proprietária rural, ou seja, faz parte apenas do horizonte de Dona Benta, pois ela ocupa uma posiçáo de detentora dos recursos materiais e, portanto, tinha a função de administrar o sítio. Assim, representa uma mulher que se liberta dos afazeres domésticos à custa de outra mulher: Tia Nastácia. Dona Benta só pode ser vista como uma representante do feminismo por ter alguém para realizar as tarefas do lar. Neste sentido, a questão das diferenças étnico-raciais e intragêneros também deve ser considerada. A mulher branca e especializada em outros conhecimentos conta com o serviço doméstico de outra mulher que, por ocupar a posiçấo de criada e ex-escrava, não conta com os avanços e com as reivindicaçôes do movimento feminista.

Podemos perceber que Dona Benta é uma mulher que teve algum acesso à educaçáo, aquela que, segundo Bicalho (1989, pp.81-82), teria beneficiado parte da população feminina urbana que até o fim do século XIX e início do XX, era alheia aos progressos do ensino e da "cultura".

A educação, por conseguinte, aparece como a condição racional da sua emancipaçáo, mas para uma mulher como Tia Nastácia, analfabeta e considerada como sem "cultura nenhuma" pelos habitantes do sítio, resta a submissáo à Dona Benta. Neste sentido, pode-se supor que Dona Benta não atende à categoria de "mulher rural clássica”, mas de patriarca/matriarca, ou seja, aquela que, detendo os meios de produção, tem algum acesso à cultura, à educação e ao cosmopolitismo. Quanto ao matriarcado, nossa análise entende que no Sítio do Pica-pau Amarelo, ele se diferencia, mas não de todo, da estrutura patriarcal que, na acepção de Roberto Schwarz (2001), teria sido no Brasil uma doutrina autoritária a partir da qual a família ofereceria o paradigma a ser seguido pela sociedade.

É essa "autoridade cordial" que podemos notar na personagem de Dona Benta. Suas açôes estão pautadas numa autoridade máxima. É ela quem estabelece as regras de conduta que as outras personagens devem seguir e também quem define a ordem econômica e organizacional da casa e da propriedade. Mas, se age como uma matriarca tradicional de um lado, ao mesmo tempo tem um olho no planejamento, no mercado e na produçáo racional, demonstrando sua face de proprietária agrária moderna.

Podemos notar na obra de Lobato que o narrador do Sítio - assim como o seu autor em outros ensaios e artigos - define um "tipo ideal" de proprietário rural: empreendedor, culto, apreciador e adepto dos conhecimentos científicos, preocupado com os danos que a falta de fertilizantes pode causar ao solo e adepto também das técnicas modernas de cultivo. Esse "tipo ideal" seria Dona Benta que consegue conjugar o conhecimento intelectual com a ação. A ma(pa)triarca possuiria uma visão objetiva, neutra e científica dos problemas de gestáo técnica da "sua nação", por isso saberia aconselhar a coisa certa a ser feita. Mas toda esta vocação modernizante não se estenderia à Tia Nastácia, que continuaria na condição arcaica de criada.

No livro Seröes de Dona Benta (1937), a matriarca passa às crianças alguns ensinamentos sobre ciência e, através de suas intervençôes, podemos perceber algumas carac- 
terísticas que comprovam que mesmo no Brasil idealizado no Sítio do Pica-pau Amarelo persiste a ambiguidade do Brasil real, situado historicamente: a convivência de dois diferentes tipos de sociedade, uma herdeira da sociedade escravista e tradicional e outra capitalista e moderna.

\section{PEDRINHO: O FORMULADOR DE PROJETOS}

Entre as crianças, Pedrinho é a personagem que mais se destaca na formulação de planos, cujas ideias são as mais mirabolantes possíveis. Ele é, no sítio, um habitante esporádico, pois lá só passa o período de férias escolares. Essa personagem representa o pragmatismo lobatiano. As ideias mais ousadas partem da sua imaginação. Exemplo disso é a formulação de um projeto que visa à exploração de petróleo no sítio como contada em $O$ poço do Visconde.

Pedrinho, para solucionar esse déficit nacional, chama toda a responsabilidade para os habitantes do sítio. Se eles não resolvessem o problema, o Brasil conservaria sua posição dependente econômica e tecnologicamente. Todos possuem características importantes que podem auxiliar na abertura dos poços. É Pedrinho quem organiza o espaço onde as aulas técnicas e científicas do Visconde vão ser ministradas. O garoto, ao comunicar ao sabugo de milho sua ideia, fica sabendo que o mesmo se propóe a ser o professor de geologia, já que, sem saber algo da história da terra, não seria possível pensar em petróleo. Pedrinho fica muito empolgado e avisa a todos os outros que as aulas iriam começar naquele mesmo dia: "Foi assim que começou o petróleo no Brasil" (LOBATO, 1968, p.5).

As crianças, a cada explicação de Visconde, se interessam cada vez mais, abismadas perante a falta de exploração dos nossos recursos naturais, principalmente após saberem da nossa capacidade geológica em produzir petróleo:

- Então porque não se perfura no Brasil?

- Porque as companhias estrangeiras que nos vendem petróleo não têm interesse nisso. E como náo se tem interesse nisso foram convencendo o brasileiro de que aqui, neste enorme território, não faria petróleo. E os brasileiros bobamente se deixaram convencer? (ibidem, p.51).

A crítica aqui é dirigida aos interesses dos trustes internacionais do petróleo, que impossibilitavam a entrada de novos países na concorrência, já que um dos objetivos seria o controle do preço e o monopólio do produto por um grupo de países. O objetivo de Pedrinho era inserir o sítio/Brasil nessa ordem. Por isso, a todo o momento oferece um exemplo nítido da necessidade da nossa autonomia petrolífera. Pedrinho decide pelos outros habitantes que as aulas devem ser ministradas ao ar livre, pondo em prática os conhecimentos aprendidos. "É fazendo que o homem aprende, não é lendo, nem ouvindo discursos. Eu quero ciência aplicada..." (LOBATO, 1968, p.72; grifos nossos). 
Nessa passagem, percebemos a crítica explícita destinada aos bacharéis, nossos intelectuais, em sua maioria membros da elite agrária do país, que na concepçâo de Lobato eram homens sem ação. Para o autor, eram verdadeiros parasitas sociais, pois seus conhecimentos náo eram aplicados na prática para solucionar os problemas que afetavam a maioria da populaçáo pobre brasileira, mas serviam apenas para serem exibidos nos discursos ou para a aquisição de cargos públicos.

No sítio, esse parasitismo não existe, pois todos os habitantes articulam o saber ao fazer, sempre buscando melhorar nossa situação de atraso para que o país progrida. Neste sentido, concordamos com Campos quando este afirma: "Obra engajada, a literatura infantil de Lobato nos apresenta a proposta 'desenvolvimentista' deste autor para o Brasil: o progresso é categoria central que percorre toda a obra [...]" (CAMPOS, 1986, p.125).

Assim as crianças preparavam tudo para iniciar a perfuração dos poços quando certo dia, enquanto estavam reunidos na sala de jantar para a refeição, Dona Benta pergunta aos netos o que eles fariam com o dinheiro que iriam lucrar com o petróleo e Pedrinho, como bom empresário capitalista, diz que queria viajar para conhecer o mundo: “- Por que, vovó, como posso saber de que modo empregar meus capitais, se nada conheço do mundo? Tenho de, primeiramente, estudar o mundo para verificar o que o mundo mais precisa, não acha?” (LOBATO, 1968, p.100).

Todos os habitantes fazem propostas práticas e concretas que visam o bom funcionamento da sociedade capitalista, tendo como modelo sempre os Estados Unidos. No Brasil, por exemplo, a necessidade vista como imprescindível era a perfuração dos poços de petróleo e, quando esse processo inicia, o sítio se transforma e ganha ares de urbanidade. Tal processo de modernização parte das crianças, a geração mais nova do sítio. No círculo dos adultos, entretanto, permanecem relaçôes como as de mandonismo, tal como exercida por Dona Benta em relação a Tio Barnabé e Tia Nastácia.

É insistindo na formação da criança que Lobato dá continuidade aos aprendizados científicos no livro Seróes de Dona Benta (1937). E aqui, novamente, é Pedrinho quem sugere à avó que ela ministre seróes científicos, pois nos livros ele não encontrava facilidade e nem clareza para entender o assunto: "- Sinto uma comicháo no cérebro, disse Pedrinho - Quero saber coisas. Quero saber tudo quanto há no mundo [...]” (LOBATO, 1966, p.8). Ou seja, as crianças estariam abertas para o futuro e a transformação, seriam capazes de absorver os conhecimentos e dar-lhes aplicação prática sem faltar uma pitada de irreverência, muito pragmatismo e grande dose de criatividade.

\section{NARIZINHO: A REPRESENTANTE DA RESPONSABILIDADE SOCIAL}

É relatando a história da menina de nariz arrebitado que Lobato se envereda para o gênero literário infantil. Narizinho é a encantadora neta de dona Benta, que vive com ela no sítio. Nos livros, seus pais nunca são citados, desde que nascera fora criada pela avó com o auxílio de Tia Nastácia. Dona Benta, portanto, é a única responsável, mencionada 
no livro, pela neta. Sua companheira inseparável é a boneca Emília. A menina representa em muitas passagens a bondade e o respeito que sua boneca muitas vezes náo possui. Ao contrário de Emília, as colocaçôes de Narizinho são resultantes de uma reflexão, o que muitas vezes faz com que sua vivacidade e sua espontaneidade sejam apagados.

Narizinho náo escapa de determinados valores passados por Dona Benta. Em uma passagem do livro Reinaçôes de Narizinho, Pedrinho chega a afirmar que "apesar" de a prima viver na roça, seria muito mais inteligente e esperta que as meninas que moravam na cidade. Neste caso, podemos inferir que tal esperteza fora adquirida através da vivência com a avó e seus ensinamentos.

A menina possui ética e refinamento na expressão de sua fala, o que pode ser observado numa passagem de O Poço do Visconde, onde Dona Benta, ao repreender Emília sobre sua forma de falar, ouve a seguinte resposta da boneca:

-Dona Benta, a senhora me perdoe, mas quem torto nasce, tarde ou nunca se endireita. Nasci torta. Sou uma besteirinha da natureza - ou dessa negra beiçuda que me fez. E, portanto, ou falo como quero ou calo-me. Isso de falar como as professoras mandam, que fique para Narizinho. Pão para mim é pão; besteira é besteira - nem que venha da Inglaterra ou dos Estados Unidos. Cá comigo é ali na batata. (LOBATO, 1968, p.63.)

Narizinho é uma "menina real" que, conforme Emília, deve obedecer a determinadas regras de conduta. Já a boneca não tem compromisso como os seres humanos, não passa de um acidente da natureza, que age como humano, mas sem necessidade de ter uma ética, de agir de acordo com as condutas consideradas socialmente corretas.

Narizinho é nomeada a Diretora Comercial da Companhia de Petróleo Donabentense, por isso Dona Benta questiona o que fariam com o dinheiro gerado com o lucro da venda do líquido, que já havia atingido a marca de 17 milhôes de cruzeiros. Enquanto Pedrinho, como vimos no item anterior, propóe-se a viajar para aumentar seus conhecimentos e os lucros do empreendimento, Narizinho propóe a construção de boas escolas profissionais para os caboclos da regiâo, médicos e "casas decentes e higiênicas" para os trabalhadores. Percebemos, portanto, que o deslumbre se reverteu em responsabilidade social por parte da menina. As transformaçóes da Vila do Tucano Amarelo foram inúmeras. Uma delas foi a Escola Técnica de Narizinho, que:

[...] tornou-se um padráo copiado pelo País inteiro. Os rapazes e as raparigas que lá se diplomavam em inúmeros ofícios eram disputados a peso de ouro. "aqui se aprende de verdade" era o letreiro que havia na fachada do estabelecimento - e aprendia-se mesmo. (ibidem 1968, p.222.)

Além dessa escola, a menina também sugeriu que "casas de abrigo" fossem criadas, assim os viajantes poderiam ser acomodados sem pagar nada, o que, na opiniáo dela era "a evolução dos antigos ranchos de tropeiros" (ibidem, p.223; grifos nossos). 
A responsabilidade social que Narizinho propóe tem como objetivo o aumento da eficiência dos trabalhadores rurais, agora transformados em operários "adaptados" à concepção fordista de produção. Narizinho representa, portanto, a ética lobatiana que pode ser observada através dos seus livros e artigos destinados ao público adulto. Ética pautada na crítica a uma elite intelectual que nada fazia para amenizar a miséria moral, física e econômica da nossa população rural. Seu desejo se concretiza no plano da utopia, onde consegue imaginar uma sociedade industrial, moderna e civilizada por meio do trabalho, da técnica e da educação científica e pragmática.

\section{TIA NASTÁCIA E TIO BARNABÉ: O LUGAR DO POVO NO SEIO DA NAÇÃO}

No final do século XIX e início do XX, a intelectualidade nacional tinha preocupaçáo com o arcaísmo que predominava na mentalidade da maior parte da população brasileira. A partir de um "novo" processo social e ideológico que se instaurava no país, especificamente nos grandes centros urbanos, questionava-se quem seriam os protagonistas das mudanças que se faziam necessárias. Diversos intelectuais, inclusive Lobato com sua literatura infantil, tiveram papel importante nas transformaçôes que se processaram naquele momento. Em grande parte dos autores que pensam os destinos e as possíveis transformaçóes da nação e da mentalidade nacional, o povo não aparece como condutor ou como sujeito social, mas sim como uma massa a ser conduzida pelo pensamento inovador.

No caso de Lobato, o povo, representado por Tia Nastácia e Tio Barnabé, não participaria do processo de modernização iniciado pelo restante dos habitantes, nem opinaria sobre a abertura de poços de petróleo em terras brasileiras. Apenas assistiriam a um projeto colocado em prática pelas crianças, pelo sabugo científico e pela boneca Emília, sempre com o respaldo e apoio de Dona Benta. Todos os habitantes, após a abertura dos poços, são nomeados para a administraçáo da recente refinaria de petróleo, mas Tia Nastácia e Tio Barnabé são mantidos na velha condição de criados para trabalhos braçais: a primeira continua trabalhando em casa, cozinhando para todos e, o segundo, continua morando nos fundos das terras de Dona Benta.

Para Lobato, nem os nossos operários estavam capacitados para uma industrialização nacional, tanto é que em $O$ Poço do Visconde os operários contratados para abrirem poços de petróleo no sítio de Dona Benta foram importados, vindos de vários países que já exploravam o produto: "[...] um rumaico, dois alemães, dois argentinos. Os petroleiros só arranjam bons especialistas nos países que já têm exploração de petróleo" (ibidem, p.114). Aqui se mantém a crença da imigração como redenção dos problemas nacionais quanto à mão de obra qualificada, ideologia predominante principalmente no final do século XIX. Somente quando a indústria do petróleo se instaura no sítio/Brasil é que os operários brasileiros passam a trabalhar para o seu desenvolvimento. Situação representada pela personagem de Chico Piramboia, um caboclo que só vagueava pelos campos, cheirando a pinga, mas que depois que começa a trabalhar na indústria petrolífera, 
seguindo a lógica fordista de produção, recebeu casa, educaçáo técnica e incentivo para o trabalho, deixando assim de representar o caboclo que vivia adoentado. Porém, apesar de ter conquistado tal status, ele não participa do processo de industrialização, nem sob a condiçáo de operário. Apenas depois do país ter se modernizado é que ele consegue uma profissão e um espaço para trabalhar no desenvolvimento dessa nação projetada no Sítio do Pica-pau Amarelo por Lobato. Isto significa que nesse projeto de nação haveria papéis definidos - e definidores de posiçôes sociais a serem ocupadas por seus habitantes.

Em termos de projeto nacional, esse processo marcaria uma inclusão do povo na construçáo de uma nação racional brasileira, mas a participação dessa parcela se daria no momento em que os trabalhadores passassem por um processo educacional com fins práticos, técnicos e competentes. Deveriam estar aptos para operarem máquinas modernas, e também terem conhecimentos de práticas modernas. Somente depois disso o povo estaria preparado para fazer parte do processo de construçáo da nação. Como vimos, este foi o caso do caboclo Chico Piramboia.

Portanto, ao propormos uma incorporaçáo de Lobato na galeria dos principais intérpretes do Brasil, notamos que sua literatura infantil expressa o tempo social em que vivia: a ideia de progresso, de um pensamento nacional fundamentado nos problemas que o país enfrentava, de educação e letramento para o povo, industrialização e do fim do modelo agrário-exportador. Para a realizaçáo de todas essas propostas, um pensamento prático e livre das amarras do tradicional bacharelismo.

\section{CONSIDERAÇÕES FINAIS}

Segundo nossa leitura, a obra de Monteiro Lobato endereçada para as crianças pode ser inscrita entre aquelas que tentaram fazer um diagnóstico da sociedade brasileira e formular um modelo de país para o futuro, destinado a convencer as novas geraçôes. É neste sentido, e seguindo as pistas de Antonio Candido, Erich Auerbach e Roberto Schwarz, que procuramos fazer uma aproximação de sua literatura com o contexto, pensando-a como "crítica social". Porém, na sua obra também ressoam as ambiguidades do país real de onde o autor colhe a matéria concreta da sua literatura. Ou seja, o esforço do escritor para a construção, ainda que imaginária, de um país moderno acaba esbarrando e convivendo com elementos do arcaísmo que se sobrepóe às transformaçóes sociais

modernizantes. É assim que, nos momentos cruciais, Lobato recorre às personagens mágicas para superar entraves que a estrutura nacional não permitia ainda vislumbrar como caminho histórico.

Ainda neste sentido, o aspecto mais problemático do projeto de nação lobatiano está no lugar reservado ao povo no contexto da nação. Este seria sempre formado por uma massa a ser conduzida por pensadores e intelectuais críticos e inovadores. $\mathrm{O}$ povo, nas figuras de Tia Nastácia e Tio Barnabé (e Chico Piramboia), não pertence à nação moderna enquanto não for absorvido como mão de obra. Aliás, os dois personagens negros parecem 
não ter lugar nos destinos da nação futura, pois na fantasia não transcendem a condição de criados, vivendo do favor da velha proprietária. Um arranjo carregado de simpatia, mas que condenava à permanência essas relaçóes herdadas do tempo do cativeiro.

Deste modo, no sítio/Brasil de Lobato conviveria moderno e arcaico como conviveriam na vida nacional. O sítio de Dona Benta, no entanto, teria aderido com mais rapidez às perspectivas modernizantes no sentido da técnica, da tecnologia e da educação pragmática, que só encontraria lugar em terras brasileiras muitas décadas mais tarde. A modernidade, porém, pensada como participação política e igualdade de direitos civis, não seria projeto de nação nem lá nem cá. Nesses termos, a modernização conservadora brasileira estava na obra e na utopia do pensador como estava na matéria concreta de lhe deu subsídios para criar a nação do Pica-pau Amarelo.

Assim sendo, ao interpretarmos a obra infantil de Monteiro Lobato como uma espécie de projeto para uma naçáo, percebemos que o autor vacila em suas prioridades para um Brasil futuro. Não existe uma aceitaçáo exclusiva de um "capitalismo verdadeiro", apesar dessa ideia ser, muitas vezes, preponderante. É como se o melhor do arcaico - as relaçóes pessoais, sentimento de comunidade, o sítio, a casinha branca - fosse mantido e incorporado ao melhor do moderno - a ciência, o petróleo, a indústria, a boa saúde do trabalhador e, principalmente, o pragmatismo. Elementos advindos fundamentalmente da magia e do sonho de sintetizar o Brasil, o sentimento nacional e a cultura popular com as novas possibilidades que poderiam oferecer uma metrópole.

\section{REFERÊNCIAS BIBLIOGRÁFICAS}

ADORNO, Sérgio. Os aprendizes do poder: o bacharelismo liberal na política brasileira. Rio de Janeiro: Paz e Terra, 1988.

AUERBACH, Erich. Mimesis: a representação da realidade na literatura ocidental. São Paulo: Perspectiva, 2007.

AZEVEDO; CAMARGO; SACCHETTA. Monteiro Lobato: furacão na Botocúndia. São Paulo: Senac, 1997.

BICALHO, Maria Fernanda Baptista. "O belo sexo: imprensa e identidade feminina no Rio de Janeiro em fim do século XIX e início do século XX”. In: COSTA, Albertina de O.; BRISCHINI, Cristina (orgs.). Rebeldia e submissão: estudos sobre a condiçáa feminina. São Paulo: Fundação Carlos Chagas, 1989, pp.80-112.

CAMPOS, André Luiz Vieira de. A república do Pica-pau Amarelo, uma leitura de Monteiro Lobato. São Paulo: Martins Fontes, 1986.

CANDIDO, Antonio. Formação da literatura brasileira: momentos decisivos (1750-1836). São Paulo: Martins, 1959.

"A literatura de dois gumes". In: A educação pela noite e outros ensaios. São

Paulo: Ática, 1989.

FREYRE, Gilberto. Sobrados e mucambos. Rio de Janeiro: Record, 2006. 
. "Negros e Negras em Monteiro Lobato". In: LOPES, Eliane M. T.; GOUVÊA, Maria C. S. (orgs.). Lendo e escrevendo Lobato. Belo Horizonte: Autêntica, 2001b, pp.62-85.

LAJOLO, Marisa; ZILBERMAN. Literatura infantil brasileira. São Paulo: Ática, 1994. LOBATO, Monteiro. O Poço do Visconde. São Paulo: Brasiliense, 1950.

. Serōes de Dona Benta. São Paulo: Brasiliense, 1957.

Cidades mortas. São Paulo: Brasiliense, 1959.

. Mr. Slang e o Brasil. São Paulo: Brasiliense, 1959b.

. Escândalo do petróleo e do ferro. São Paulo: Brasiliense, 1959c.

. Reinaçôes de Narizinho. São Paulo: Brasiliense, 1959d.

. Histórias de Tia Nastácia. São Paulo: Brasiliense, 1960.

. Geografia de Dona Benta. São Paulo: Brasiliense, 1962.

- A barca de Gleyre. São Paulo: Brasiliense, 1964, tomo II.

O saci. São Paulo: Brasiliense, 1972.

- A reforma da natureza. São Paulo: Brasiliense, 1973. A chave do tamanho. Sáo Paulo: Brasiliense, 1973b.

Negrinha. São Paulo: Brasiliense, 1987.

Urupês. São Paulo: Brasiliense, 1994.

PASSIANI. Enio. Na trilha do Jeca: Monteiro Lobato e a formação do campo literário no Brasil. Bauru: Edusc, 2003.

SCHWARZ, Roberto. "As idéias fora do lugar". In: Ao vencedor as batatas: Forma literária e processo social nos inícios do romance brasileiro. São Paulo: Duas Cidades, 2001.

VASCONCELLOS, Zinda Maria Carvalho de. O universo ideológico da obra infantil de Monteiro Lobato. São Paulo: Traço, 1982.

ZILBERMAN, Regina. Como e por que ler a literatura infantil brasileira. Rio de Janeiro: Objetiva, 2005. 